\title{
CTDNEP1 Gene
}

National Cancer Institute

\section{Source}

National Cancer Institute. CTDNEP1 Gene. NCI Thesaurus. Code C102888.

This gene plays a role in protein dephosphorylation. 